\title{
PENGEMBANGAN USAHA PRODUKSI JAMUR TIRAM KELOMPOK WANITA TANI BERBASIS WILAYAH
}

\author{
Hernawati $^{1 *}$, Aisah Jamili ${ }^{2}$, Didin Hadi Saputra ${ }^{3}$ \\ ${ }^{1 *}$ Fakultas Pertanian Universitas Nahdlatul Wathan Mataram \\ ${ }^{2}$ Fakultas Pertanian Universitas Nahdlatul Wathan Mataram \\ ${ }^{3}$ Fakultas IImu Adminitrasi Universitas Nahdlatul Wathan Mataram \\ Corresponding author : \\ E-mail : ernawati68459@gmail.com
}

\section{Diterima 8 September 2019, Disetujui 16 September 2019}

\begin{abstract}
ABSTRAK
Usaha bersama jamur tiram yang dijalankan oleh Kelompok Wanita Tani "Karya Muda" di Desa Kebun Ayu Kecamatan Gerung Kabupaten Lombok Barat dengan tujuan membantu keuangan keluarga memiliki permasalahan, diantaranya terbatasnya jumlah produksi jamur, akses permodalan manajemen usaha, sumber daya manusia yang terbatas, belum mampu mengadministrasikan, mendokumentasikan hasil produksi jamur tiram melalui media pemasaran agar output mampu beredar di jaringan pasar yang lebih luas dan dikenal oleh masyarakat luas. Solusi yang ditawarkan memfasilitasi dalam proses produksi yaitu memberikan bantuan alat pres baglog, pelatihan pengolahan hasil produksi jamur, perluasan akses pasar, meningkatkan kemampuan manajerial, meningkatan pendapatan mitra, serta mendaftarkan merek dagang mitra. Hasil dalam program kemitraan masyarakat ini adalah memberikan bantuan alat pres baglog untuk meningkatkan produksi jamur, memberikan penyuluhan dan pelatihan pengolahan hasil yaitu pembuatan krispy, bakso dan nughet jamur, setelah pelatihan masyarakat mampu mengolah jamur menjadi produk olahan yang sehat dan produk olahan dari mitra bisa diikutsertakan dalam pameran yang diadakan di Kantor Bupati Lombok Barat.
\end{abstract}

Kata kunci : Produksi, Manajemen, Pemasaran, Jamur Tiram

\begin{abstract}
The joint venture of oyster mushrooms run by the "Karya Muda" Women's Farmer Group in Kebun Ayu Village, Gerung District, West Lombok Regency with the aim of helping family finances has problems, including the limited number of mushroom production, access to capital for business management, limited human resources, have not been able to administer, document the results of the production of oyster mushrooms through marketing media so that output is able to circulate in a wider market network and is known by the wider community. The solution offered facilitates the production process, which is to provide assistance with press baglog tools, training on mushroom production results, expanding market access, increasing managerial skills, increasing partner income, and registering partner trademarks. The results of this community partnership program are providing baglog press tools to increase mushroom production, providing counseling and results processing training, namely making krispy, meatballs and mushroom nughets, after training the community is able to process mushrooms into healthy processed products and processed products from partners can be included in the exhibition held at the West Lombok Regent's Office.
\end{abstract}

Keywords : Production, Management, Marketing, Oyster Mushrooms.

PENDAHULUAN

Analisis situasi

Pembangunan sub sektor pertanian sebagai bahan interval pembangunan pertama mempunyai peranan cukup penting dalam upaya peningkatan pendapatan petani. Tehnologi pertanian dalam dunia usaha tani merupakan suatu elemen strategi dan sekalius menjadi prasyarat dalam peningkatan ketahanan pangan dan pengembangan system agribisnis pertanian di Indonesia.
Kegiatan usaha pertanian terutama yang berbasis wilayah merupakan kegiatan utama masyarakat tani. Kegiatan ini merupakan penggerak ekonomi masyarakat pedesaan yang sebagian besar masyarakat Desa Kebun Ayu Kecamatan Gerung merupakan masyarakat petani.

Desa Kebun Ayu memiliki peluang yang baik untuk mengembangkan jamur tiram. Prospek pengembangan usaha jamur tiram di daerah ini cukup terbuka dilihat dari keadaan 
lingkungan yang cocok untuk syarat tumbuh pertumbuhan jamur, selain itu ketersedian limbah pertanian sebagai bahan baku untuk terlaksananya inovasi teknik budidaya jamur ini tersedia sepanjang waktu. Hal ini menjadi potensi utama untuk pelaksanaan kegiatan ini.

Produksi jamur tiram di desa kebun ayu kecamatan gerung sangat berpotensi untuk dikembangkan dan mampu memiliki nilai ekonomi yang sangat tinggi karna jamur tiram bisa diolah menjadi beberapa produk tidak hanya bisa dikonsumsi langsung dalam bentuk jamur akan tetapi bisa diproduksi dalam bentuk makanan ringan yang sehat dan digemari dari berbagai kalangan, selain dalam bentuk makanan ringan (snack) bisa juga diproduksi menjadi bakso jamur, krispy dan lain lain yang memiliki daya tahan lebih lama dan memiliki nilai ekonomi tinggi.

Adapun peserta program kegiatan ini terdiri dari satu mitra. Dimana mitra tersebut adalah masyarakat yang terlibat dalam Kelompok Wanita Tani (KWT) Desa Kebun Ayu Kecamatan Gerung Kabupaten Lombok Barat. Kelompok Wanita Tani ini adalah ibu ibu rumah tangga yang memproduksi jamur tiram yang belum memiliki kemampuan maksimal dalam meningkatkan manajemen usaha, keterampilan dalam menghasilkan produk baru, mengelola keuangan pada usahatani jamur, meningkatkan hasil produksi yang sesuai dengan permintaan pasar baik ditingkat lokal maupun nasional, meningkatkan promosi dan perluasan wilayah pemasaran hasil jamur, belum mampu berusaha untuk senantiasa menjaga kontinuitas hasil produksi

Kelompok Wanita Tani ini khusus ibuibu rumah tangga yang terlibat didalamnya, selama ini ibu-ibu di desa kebun ayu sudah banyak yang diberdayakan dan sudah bergabung dalam KWT akan tetapi tujuan utama dari mitra ini masih pada tujuan utama yaitu peningkatan penghasilan keluarga atau sebagai pemenuhan kebutuhan keluarga saja.

\section{Permasalahan Mitra}

Kegiatan pertanian terutama yang berbasis tradisional di pedesaan merupakan kegiatan utama masyarakat tani. Kegiatan ini merupakan salah satu penggerak ekonomi masyarakat pedesaan yang sebagian besar masyarakat Kebun Ayu Kecamatan Gerung merupakan masyarakat petani.

Sehubungan dengan pemberdayaan petani dari pemerintah dengan pemanfaatan tehnologi tepat guna yang khususnya Alat Pengolahan Pertanian dan Pengolahan Hasil Pertanian sehingga Kelompok Wanita Tani Mitra mengharapkan pembinaan oleh instansi terkait dan bisa memperoleh bantuan alat dalam melaksanakan usaha tersebut.

Permasalahan yang dihadapi oleh Mitra adalah jumlah produksi karna dalam pengisian baglog dengan cara manual sehingga membutuhkan waktu dan tenaga yang cukup banyak, permasalahan lain yang dihadapi juga adalah mitra belum mampu mengolah hasil produksi jamur pada saat jumlah produksi yang dipasarkan tidak terjual semuanya selain itu juga permasalahan yang dihadapi oleh mitra adalah belum mampu manajemen usaha jamur secara maksimal dan belum mampu memasarkan produk jamur secara luas yang selama ini pemasarannya hanya dilakukan di pasar tradisional lokasi mitra.

\section{Solusi yang ditawarkan}

Solusi yang ditawarkan dengan adanya kegiatan PKM ini adalah sebagai berikut:

1. Kapasitas produksi jamur Kelompok Wanita Tani (KWT) Karya Muda dapat meningkat, dengan cara meningkatkan dan mengelola manajemen usaha lebih baik lagi

2. Meningkatkan perluasan pasar usaha produksi jamur KWT Mitra dengan cara :

a. Membuat mutu produk dengan membentuk system quality control terhadap produksi jamur sapu dengan cara menugaskan satu orang pengurus kelompok sebagai pengawas (supervisor) terhadap kualitas produksi jamur, sekaligus terampil dalam pemeliharaan (maintenance) sarana peralatan memproduksi jamur.

b. Mendaftarkan merk dagang UKM Mitra ke dinas berwenang guna meningkatkan kepercayaan (brand image) produk UKM Mitra di masyarakat dan meningkatkan nilai jualnya.

3. Meningkatkan pengolahan jamur tiram dengan menggunakan tehnologi tepat guna.

4. Meningkatkan kemampuan manajerial dengan pendampingan manajemen usaha

5. Meningkatkan pendapatan UMKM dengan naiknya volume produksi karena menggunakan teknologi informasi dan teknologi tepat guna (TTG).

\section{METODE PELAKSANAAN}

Metode pelaksanaan dalam kegiatan ini dapat diartikan sebagai cara atau teknik penyampaian materi pelatihan berbasis wilayah oleh para pakar kepada mitra baik secara langsung maupun tidak langsung, agar mereka tahu, mau dan mampu menerapkan inovasi (teknologi baru). 
Metode pelaksanaa PKM yang ditawarkan tim pengusul pada mitra Kelompok Wanita Tani "Karya Muda" meliputi tahapan-tahapan yang dilakukan secara sistematis dan berkesinambungan sebagai berikut :

a. Mengadakan koordinasi tentang keberadaan kelompok mitra, serta melakukan pembinaan dan pengarahan manajemen produksi atau supply chain management melalui sosialisasi program kemitraan berbasis wilayah pemasaran

b. Mempersiapkan dan melakukan koordinasi antara team dan mitra berkaitan dengan kegiatan yang akan dilakukan melalui penyusunan jadwal kegiatan, penentuan tempat, media yang akan digunakan untuk promosi dan materi yang dibutuhkan, serta melakukan pembinaan keterampilan kelompok dalam bidang manajemen dengan mengelola manajemen usaha edukatif agar lebih menarik dan layak di kunjungi

c. Pendampingan pengembangan keterampilan kelompok usaha mitra dalam mempromosikan atau memasarkan produk

d. Peningkatan kemampuan pemasaran melalui pendampingan keterampilan kelompok mitra dalam memperluas jaringan pengunjung ke lokasi PKM dengan mempromosikan produk hasil olahan, baik secara langsung maupun marketing online melalui rancang desain teknologi informasi seperti: blog, facebook, atau twitter, serta memonitoring hasil pelaksanaan PKM secara kontinue

e. Menyelenggarakan open house produk secara terjadwal.

f. Aspek yang lain, yakni aspek sosialekonomi, yang meliputi pengaruh penerapan dan pengembangan KWT "Karya Muda" terhadap perekonomian, penciptaan lapangan kerja, dan pengaruh terhadap sektor lain di desa mitra tersebut.

\section{METODE PENDEKATAN}

Metode pendekatan yang ditawarkan yakni sosialisasi program PKM yang dilakukan di tingkat desa dengan melibatkan kelompok mitra binaan dan transfer teknologi akan di fokuskan pada kelompok sasaran yang menjadi prioritas utama, yaitu kelompok mitra Kelompok Wanita Tani "Karya Muda". Diharapkan anggota kelompok yang dilibatkan adalah anggota yang memiliki minat, berwawasan maju, mau menerima inovasi teknologi, dan mampu menularkan kepada orang lain sehingga diharapkan dapat menjadi pioner.

\section{HASIL DAN PEMBAHASAN Kegiatan Pra PKM}

Pada tahap ini, tim yang telah dinyatakan lolos dalam pendanaan PKM (Program Kemitraan Masyarakat) dari Direktorat Riset dan Pengabdian Masyarakat (DRPM) Kementerian Riset Teknologi dan Pendidikan Tinggi (Kemenristek Dikti) secara terjadwal mengunjungi lokasi desa mitra untuk menjelaskan serta melakukan koordinasi untuk persiapan kegiatan pengabdian dalam pelaksanaan program. Pada tahap ini tim PKM dari Universitas Nahdlatul Wathan Mataram memberikan penjelasan tentang rencana pelaksanaan program, seperti penyuluhan yang berkaitan dengan manajemen operasional, pelatihan pengolahan hasil, manajeman produksi, pendampingan serta pembinaan mitra PKM. Tahap pelaksanaan program sesuai dengan kesepakatan bersama antara tim pengusul dengan mitra KWT Karya Muda Desa Kebun Ayu Kecamatan Gerung Kabupaten Lombok Barat. Kegiatan sosialisasi program ini dihadiri oleh perwakilan tim PKM, mahasiswa yang terlibat dan kelompok wanita tani Karya Muda untuk melakukan diskusi dan penetuan jadwal pelaksanaan program PKM.

\section{Kegiatan Penyerahan Alat Press Baglog}

Pendampingan dan pembinaan berbasis wilayah yang dilakukan oleh tim PKM Universitas Nahdlatul Wathan Mataram meliputi membantu pengadaan alat press baglog yang digunakan untuk press atau memadatkan media baglog, sehingga kelompok mitra tidak perlu lagi menggunakan cara manual yang membutuhkan waktu lama sehingga jumlah produksi secara kuantitas bertambah sehingga kegiatan ini diharapkan dapat berdampak kepada ketertiban kegiatan operasional usaha mitra, dan keutuhan dalam mengelola serta meningkatkan kapasitas produksi jamur dan yang lebih penting lagi mampu mengolah hasil jamur menjadi produk yang memiliki nilai lebih tinggi jika terjadi kelebihan jumlah produksi. Penggunaan dan pemanfaatan tehnologi tepat guna yang khususnya alat produksi media jamur atau baglog dimana selama ini KWT menggunakan cara manual yang mengahasilkan produksi tidak maksimal sehingga tim PKM memberikan solusi memberikan bantuan alat press baglog yang bertujuan untuk meningkatkan produksi dan mengefisienkan waktu. Alat press baglog ini mampu memproduksi 5 baglog dalam waktu 1 menit yang sebelumnya dengan cara manual menghasilkan 1 baglog dalam waktu 5 menit. Sehingga dengan adanya bantuan penyediaan alat press baglog ini tim PKM mengaharapkan peningkatan produksi dan 
efisiensi biaya dan waktu. Setelah pemberian alat ini tim PKM akan terus memantau dan membina penggunaan alat tersebut supaya bisa meningkatakan produksi dan pendapatan mitra KWT Karya Muda. Berikut penyerahan alat kepada KWT Karya Muda Desa Kebun Ayu Kecamatan Gerung Kabupaten Lombok Barat.

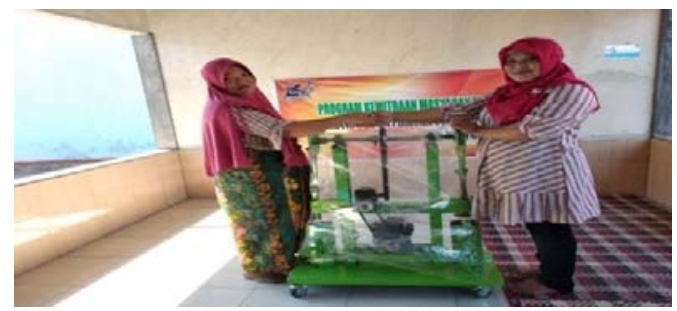

Gambar 1: Acara Penyerahan Alat Press Baglog kepada ketua Kelompok Wanita Tani Karya Muda di

Desa Kebun Ayu Kecamatan Gerung Kabupaten Lombok Barat

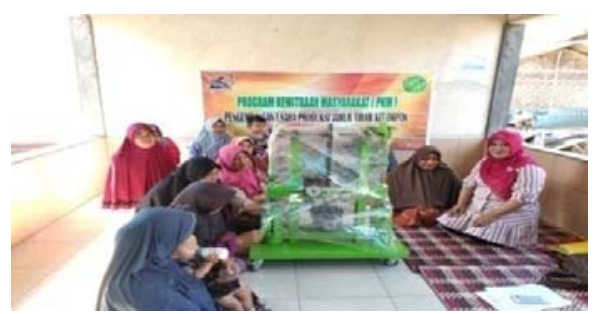

Gambar 2: Foto Bersama Kelompok Wanita Tani Karya Muda saat penyerahan alat press baglog di Desa Kebun Ayu Gerung.

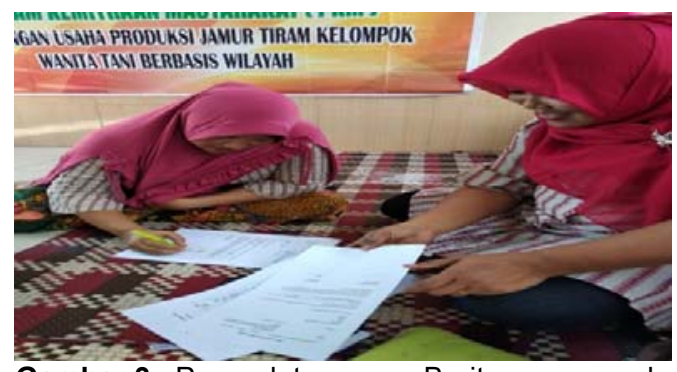

Gambar 3 : Penandatanganan Berita acara serah terima alat press baglog dari Tim PKM dengan Kelompok Wanita Tani Desa Kebun Ayu Kecamatan Gerung Kabupaten Lombok Barat.

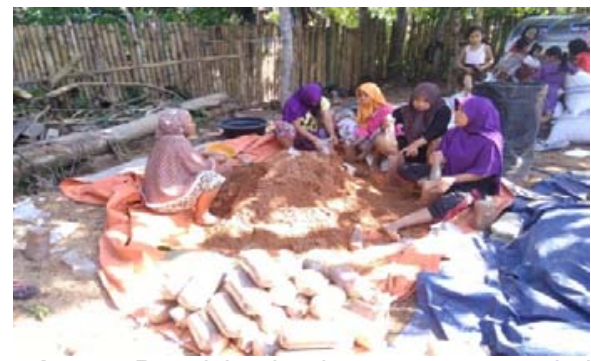

Gambar 4 : Pengisian baglog secara manual oleh mitra KWT Karya Muda Desa Kebun Ayu

Kecamatan Gerung Kabupaten Lombok Barat

\section{Kegiatan Penyuluhan dan Pelatihan}

Dalam kegiatan penyuluhan dan pelatihan, tim PKM bersama sebagian dosen yang melaksanakan pengabdian melakukan kegiatan pelatihan mengenai manajemen operasional dan produksi jamur yang dilaksanakan di balai pertemuan kelompok tani di Desa Kebun Ayu Gerung, yakni sekitar tempat lokasi mitra tinggal. Lokasi pelatihan ini turut didukung dan bekerjasama dengan pihak desa Kebun Ayu dan kelompok tani tunas karya serta beberapa unsur, yakni Badan Perwakilan Desa (BPD), Badan Usaha Milik Desa (BUMDes), beberapa kepala dusun, para kader posyandu serta beberapa perwakilan dari tokoh pemuda, tokoh masyaraakat serta tokoh agama desa Kebun Ayu.

Pada kegiatan PKM (pelatihan dan penyuluhan) ini, banyak hal yang disampaikan oleh tim PKM Universitas Nahdlatul Wathan Mataram, diantaranya bagaimana proses pengajuan proposal PKM ini ke kemenristekdikti sehingga mendapatkan dana untuk kegiatan PKM bersama Mitra, proses survey awal ke lokasi PKM Kelompok Wanita Tani Karya Muda, pengumuman kelulusan proposal PKM, kegiatan awal sosialisasi program yang akan dilaksanakan berasama mitra dan pendampingan sebelum kegiatan dan pelatihan manajemen usaha produksi dan manajemen operasional, serta tindak lanjut dan luaran atau output yang dihasilkan dari kegiatan PKM, serta keberlanjutan kegiatan PKM untuk masa yang akan datang.

Kegiatan pelatihan dan penyuluhan ini juga bertujuan menghasilkan luaran tambahan lainnya, yakni peningkatan daya saing produk mitra di pasaran lokal dan regional, peningkatan edukasi mitra dengan menerapkan IPTEK dalam menghasilkan produk yang mempunyai nilai ekonomi tinggi, perbaikan tata nilai masyarakat melalui rekayasa sosial.

Kegiatan pelatihan yang dilakukan oleh tim PKM selain pelatihan manajemen usaha produksi dan manajemen operasional adalah pelatihan pengolahan jamur menjadi produk yang lebih tinggi nilai ekonominya seperti nughet jamur, bakso jamur dan krispy jamur. Berikut adalah foto kegiatan penyuluhan dan pelatihan : 


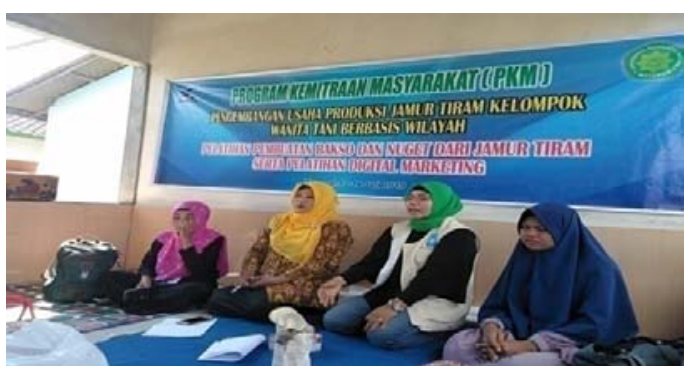

Gambar 5 : Acara Penyululuhan dan pelatihan Digital Marketing di Balai Pertemuan Lokasi Mitra PKM (KWT Karya Muda) Desa Kebun Ayu Kecamatan Gerung Kabupaten Lombok Barat

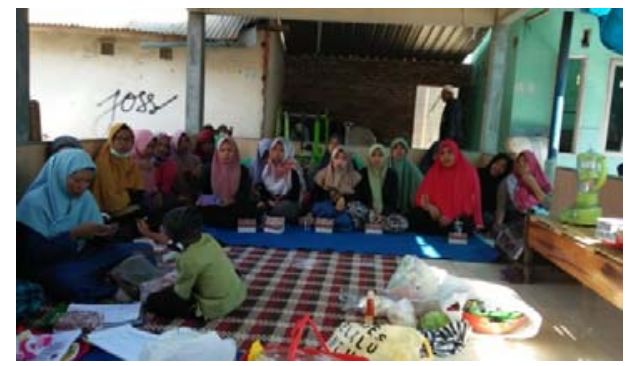

Gambar 6 : Tim PKM memberikan penyuluhan materi tentang manajemen, operasional dan pemasaran produk jamur tiram.
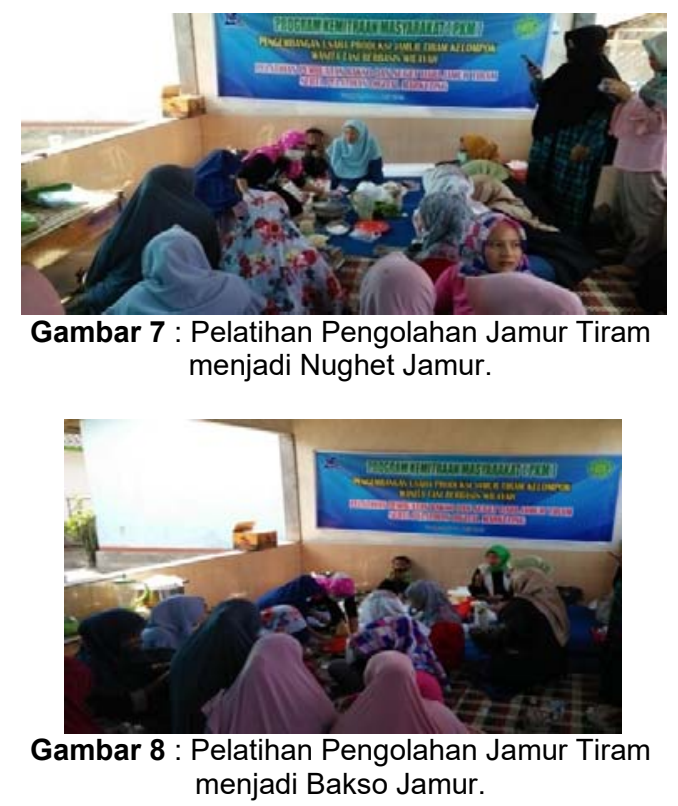

Permasalahan yang dihadapi oleh mitra diberikan solusi oleh tim PKM melalui pendampingan serta pembinaan yang efektif, akhirnya tim dari PKM Universitas Nahdlatul Wathan Mataram sepakat sesuai dengan peta tahapan awal untuk memandu serta membina para mitra untuk dapat lebih optimal dalam manajemen usaha jamur, pengolahan jamur dan membantu memasarkan produknya, baik melalui offline maupun online.
Salah satu yang paling banyak dikeluhkan oleh mitra PKM adalah keterbatasan sumber akses modal usaha UKM mitra, keterbatasan ini disebabkan oleh kurangnya akses pasar, kurang dan lemahnya akses permodalan, serta kurangnya akses informasi mitra dengan jaringan pemasaran, jaringan permodalan, serta jaringan mitra bisnis yang lebih luas, sehingga proses pelebaran atau pengembangan pemasaran yang dialami oleh mitra terkesan sempit, Oleh karena itu, dalam mengatasi hal tersebut, selain penguatan serta pengembangan yang berbentuk rekayasa sosial berbasis wilayah, namun mempunyai akses secara nasional dan tim PKM membantu membuatkan dan mengurus Izin Usaha Mikro Kecil (IUMK) dan Nomor Induk Berusaha (NIB) dengan nomor 9120208700219 tertanggal 01 Juli 2019 (Terlampir). Sehingga setelah proses penguatan pendampingan serta pembinaan ini berjalan, nantinya ada pengintegrasian yang lebih luas lagi terhadap pengelolaan keuangan/usaha dan cara mengakses tambahan modal kerja UKM mitra dengan dunia industri yang berhubungan dengan handmade product.

Untuk lebih meningkatkan dan lebih membuka akses pasar serta akses bisnis mitra PKM, diperlukan adanya sistem rekayasa sosial yang lain, dengan tujuan untuk lebih mengeksposes produk jamur dan olahannya, membuka saluran disitribusi pemasaran yang baik sangat diutamakan oleh tim PKM Universitas NW Mataram, saluran distribusi pemasaran tersebut berupa outlet atau showroom yang menampilkan hasil produk Kelompok Wanita Tani Karya Muda Desa Kebun Ayu Kecamatan Gerung. Ruang produksi dan penyimpanan produk juga masih terkesan sangat sederhana, sehingga perlu pembenahan secara keseluruhan terhadap administrasi, produksi, penyimpanan dan pemasaran pada UKM mitra

Peningkatan kuantitas dan kualitas kerja Kelompok Wanita Tani jamur tiram juga perlu ditingkatkan, agar nantinya dalam membuka akses atau jaringan pemasaran baik dalam bentuk jamur segar maupun olahannya, mereka dapat berkomunikasi dengan baik, karena untuk berkomunikasi dengan para calon konsumen, diperlukan proses komunikasi pemasaran yang baik serta memahami komunikasi personal dengan utuh, sehingga kegiatan pendidikan dan latihan (Diklat) harus rutin diadakan sehingga nantinya kegiatan pelatihan, baik manajemen usaha, pengolahan hasil jamur lebih bervariasi seperti bakso jamur, nughet, 
krispy, es krim, sate jamur dan produk lainnya dapat dijangkau pemasarannya secara luas.

\section{Pengembangan Jaringan Pemasaran (Promosi Hasil Olahan)} Kegiatan pendampingan serta pembinaan ini berlangsung selama mitra memperoleh program PKM dari Kemenristek Dikti yang di percayakan pelaksaannya kepada Universitas Nahdlatul Wathan Mataram, dan kegiatan pendampingan dan pembinaan ini akan berlanjut selamanya, dengan tujuan mitra akan mampu lebih mandiri dalam menjalankan usaha jamur, serta lebih mandiri dan mampu dalam membina mitra yang lain yang ada di lingkungan Desa Kebun Ayu Kabupaten Lombok Barat. Salah satu kriteria penting dalam mengevaluasi kelayakan dari program kemitraan masyarakat ini adalah kemampuan dan kemauan mitra untuk terus meningkatkan kapasitas produksi, peningkatan keuntungan, rekayasa sosial yang komprehensif, serta output lainnya yang mendatangkan banyak manfaat serta keuntungan, baik buat penyelanggara PKM (Universitas NW Mataram), mitra PKM (KWT Karya Muda), serta pemberi dana PKM (DRPM/Kemenristek Dikti). Hasil masa operasi selama ini yang dilakukan oleh mitra menunjukkan potensi yang layak untuk dikembangkan secara lebih luas lagi. Adapun hasil dari kegiatan PKM selain memberikan sebuah nama produk yaitu "Bale Jamur Desa Kebun Ayu" yaitu pengolahan hasil jamur menjadi sebuah produk yang bernilai ekonomi lebih tinggi seperti krispy jamur, bakso jamur, nughet jamur dan semua produk olahan ini kami pernah tampilkan pada saat bazaar dan pameran yang diadakan di Kantor Bupati Lombok Barat. Berikut kegiatan bazaar dan pameran produk olahan jamur.

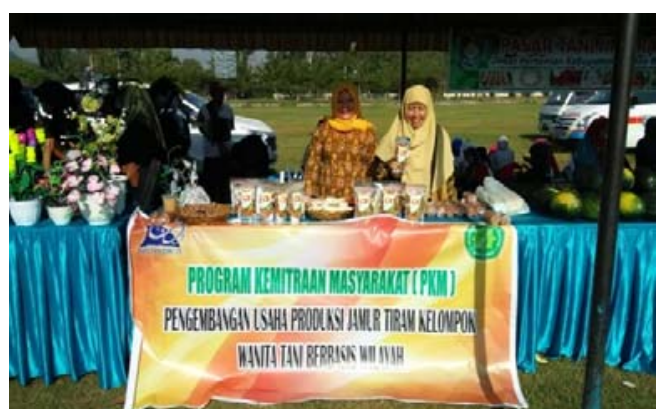

Gambar 9 : Hasil Olahan Jamur Mitra KWT Karya Muda diikutkan dalam acara Bazaar dan Pameran di Lapangan Kantor Bupati Lombok Barat.

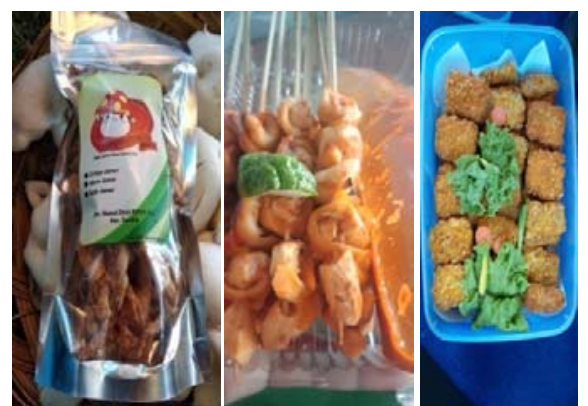

Gambar 10 : Jenis Produk Olahan Jamur (Krispy jamur, Sate jamur dan Nughet Jamur) Kelompok Wanita Tani Karya Muda Desa Kebun Ayu Kecamatan Gerung Kabupaten Lombok Barat

\section{KESIMPULAN DAN SARAN Kesimpulan}

Penguatan sentra usaha produk jamur dan olahannya harus terus ditingkatkan, tidak hanya dilokasi desa mitra saja, namun harus lebih meluas lagi ke tingkat regional serta nasional, bahkan internasional. Penguatan kegiatan ini tidak hanya dilakukan ketika program PKM berlangsung, namun harus terus berjalan secara berkelanjutan. Kegiatan PKM ini adalah peran serta aktif pendamping PKM, mitra dari pendamping yakni Kelompok Wanita Tani Karya Muda, Perangkat Desa yakni tokoh agama, tokoh masyarakat, serta unsur dari pihak ketiga, yakni dari Dinas UMKM serta masyarakat setempat.

Dalam setiap kegiatan PKM yang dilaksanakan, tentu butuh pendampingan secara berkelanjutan. Hal ini diperlukan untuk meningkatkan kreatifitas yang tinggi dan tetap signifikan dalam memberikan pencerahan kepada masyarakat berbasis wilayah dan hasil produk jamur dan olahannya. Salah satu hasil PKM yang telah memberikan hasil positif dan berdampak baik bagi masyarakat sekitar yang menjadi obyek dari kegiatan PKM adalah diberikannya alat press baglog kepada Kelompok Wanita Tani Karya Muda.

\section{Saran}

Aspek sosial ekonomis dari dampak kegiatan PKM ini yang harus dipertimbangkan adalah lokasi tersebut dekat dengan pusat kegiatan yang mendukung operasionalisasi suatu usaha seperti tempat penjualan produk jamur dan olahan, para pembeli dan lokasi yang dipilih merupakan daerah pengembangan sentra usaha jamur sehingga mempunyai dampak ekonomi yang baik serta peningkatan kesejahteraan masyarakat secara utuh serta berkelanjutan. 


\section{DAFTAR RUJUKAN}

Chazali S., 2009. Usaha Jamur Tiram Skala Rumah Tangga. Jakarta: Penebar Swadaya.

Parmijo dan Agus A., 2007. Budidaya Jamur. Jakarta: Agro Media Pustaka.

Nurhidayat, 2008. Aneka Olahan Jamur Tiram. Laboraturium Bioindustri dan Pengolahan Limbah Jurusan Teknologi Industri Pertanian.

Fakultas Pertanian. Universitas Brawijaya.

Unus Suriawira, 2003. Budidaya jamur Tiram. Yogyakarta. Kanisius. 